\title{
Social security as a developmental institution? The relative efficacy of poor relief provisions under the English Old Poor Law
}

\author{
Richard M. Smith
}

In the 1960s and 1970s, it was widely believed that 'development' in the West was both a fundamentally economically driven process and one which had exploded into life with the world's first industrial revolution, which occurred in Britain between 1780 and 1850. This was reflected in the statistical narrative of growth researched by Deane and Cole and in the influential interpretation of W.W. Rostow's Stages of Economic Growth, with its celebrated metaphor of the British economy 'taking-off' into self-sustaining flight during the early nineteenth century (Deane and Cole 1969, Rostow 1960). In many respects this general narrative continues to be influential in development policy circles today.

However, development scholars and practitioners alike need to take on board the full implications of the profound transformation that has come about during the 1980s and 1990s in historians' understanding of the nature of industrialization and associated urbanization in Britain. The new orthodoxy is a much more evolutionary model of centuries-long build-up from 1600 through to 1800 . As Table 3.1 demonstrates, during these two centuries England's economy achieved a sustained trajectory of upward economic growth, quite abnormal for all the rest of western Europe. This can be proxied by the extent of growth of the urban population in England and England's contribution to overall European urban growth from 1600 to 1800 . By 1700 England had surpassed her great rival Holland as a crucible of European commercialization and growth of the secondary sector. Thus, historians of the world's first episode of 'development' are now, following the lead of the Nobel laureate Douglass North (1981), focusing on examining the full range of economic and social institutions which could account for that exceptional performance across two centuries before steam power was first used to spin yarn in Lancashire.

One of these institutions attracting great interest is the role of the precocious 'Old Poor Law', a national social security system deemed by act of parliament to 
Table 3.1 The English share of European urban growth 1600-1800 (population in millions)

\begin{tabular}{lcc}
\hline & Total population & Urban population \\
\hline Europe & & \\
1600 & 70.6 & 5.65 \\
1700 & 75.0 & 7.13 \\
1750 & 88.5 & 8.57 \\
1800 & 111.8 & 11.85 \\
& & \\
England & & \\
1600 & 4.11 & 0.249 \\
1700 & 5.06 & 0.680 \\
1750 & 5.77 & 1.012 \\
1800 & 8.66 & 2.079 \\
& & \\
English percentage of European 'net' urban gain & \\
$1600 / 1700$ & 33 & \\
$1700 / 1750$ & 57 & \\
$1750 / 1800$ & 70 & \\
$1600 / 1800$ & 53 & \\
\hline
\end{tabular}

Source: Wrigley (1987a: 179)

operate throughout England in 1601. Though it was an institution comprised of many parts, and one that evolved over time, it is helpful to think of it as being comprised of two general elements: an 'indoor' component, which sought to provide basic assistance in the form of housing and hospitalized health care to the poor (and especially to orphans and unmarried mothers); and an 'outdoor' component, which provided cash payments and food rations to the destitute (and was available to broader sections of the population during economic downturns and episodes of harvest failures resulting in food price inflation). Both forms of assistance were 'portable', in that eligibility was not conditional upon permanent residence as a basis for membership in a particular geographical community, though assistance itself was monitored and distributed through local parishes. Recent scholarship, which this chapter surveys and extends, suggests that the Old Poor Law was instrumental in encouraging labour mobility and in providing an elementary but innovative and relatively comprehensive social safety net, which facilitated broad-based entrepreneurship and innovation by ensuring that failure in such ventures did not lead inexorably to destitution.

Over a decade has passed since Peter Solar, in a stimulating revisionist analysis of the English Old Poor Law, made a forceful case for the role it played in facilitating the distinctive character of pre-industrial economic success, achieved by 
what Wrigley has termed England's primarily 'organic economy' (Solar 1995, Wrigley 2006). Solar made a claim that, when comparisons are made between English poor relief and other systems of poverty alleviation to be found in most other areas of pre-industrial Europe, levels of English poor relief exceeded those provided elsewhere. His principal interest was in the ways that this provisioning led to certain economic efficiencies, particularly when compared with England's near neighbour France. In particular, he stressed the role played by the poor law in facilitating labour mobility, contrary to Adam Smith's view of the system and its assistance in enabling a particular type of capitalist agriculture to arise. The latter argument has subsequently been endorsed by Wrigley in his more recent attempts to chart both the causes and consequences of English agrarian success in underwriting both rapid urban growth and the shift of employment into the secondary sector well before 1750. While Solar's paper has received some comment of a critical nature, ${ }^{1}$ the argument has become tacitly accepted in many quarters.

This present chapter attempts to develop some of Solar's arguments still further and in so doing to confront some of the criticisms made against Solar's case. More is made in this current assessment of the distinctive role played by parishes as units of revenue raising and welfare distribution, particularly with regard to issues of equity and welfare citizenship. A more wide-ranging attempt is also made to extend Solar's observations about the centrality of the agrarian underpinnings of revenue generation for welfare provisioning, not just in rural but in urban industrial regions as well. Finally, certain demographic consequences that may have flowed from the operation of the system that help to account for the benign nature of the Malthusian 'positive check' when applied to English mortality in a wider European context are considered.

\section{The settlement laws, parochial residence and welfare citizenship under the Old Poor Law}

While this chapter is primarily concerned with the issue of welfare entitlements and discriminations in relation to parochial residence and particular notions of citizenship that flow from this membership or association, and is largely set within a pre-industrial English context, it is also concerned with a key issue in the comparative treatment of these matters over time within England and between England and her continental European neighbours between 1600 and 1800. Some of these matters will have to be drawn with broad brush strokes, given the scope of the chapter. The issue underpinning the bulk of the chapter, and one that has long preoccupied historical demographers of pre-industrial societies, concerns the susceptibility of their populations to demographic crises associated with short-term economic difficulties, primarily due to dearth and harvest deficiencies.

It was over twenty years ago that the Cambridge Group for the History of 
Population, in a demographic reconstruction of England from 1541-1871, was able to establish how much of the variation in mortality was explicable in terms of variation in the price of wheat in the same year and the four subsequent years. For England from the mid-sixteenth to early nineteenth century, it was discovered that price variation accounted for only 16 percent of the variation in mortality and that most of this was the result of nine years of extreme upward fluctuations in prices. It was also revealed that the net effect of price fluctuations was essentially zero and that runs of years of high prices had no effect on mortality (Wrigley and Schofield 1981: 371-82). The contrast with other parts of Europe is striking. In France, for instance, 46 percent of the fluctuations in the non-infant death rate in the seventeenth and eighteenth centuries were associated with grain price fluctuations and runs of high prices had an extra effect on mortality (Galloway 1981). Clearly we would need to consider a host of factors to do with the nature of agrarian institutions (particularly legal and tenurial issues), marketing and productivity in a comprehensive comparison of these situations. In this present discussion, a set of issues to do with welfare provisioning - and particularly to do with revenue raising through taxation at the level of the politically constituted parish, as well as the criteria by which eligibility for the receipt of relief were determined - are singled out for comparative consideration.

One theme that looms large in the research of early modernists who have focused their attention on poor relief in early modern England has been, from the mid-sixteenth century, the increasing government interference with, centralization and emerging uniformity of, poor-relief provision. For the most part this research turns a blind eye to the medieval situation. If attention is given to the earlier period it is usually granted within the framework of discussions of voluntary charitable activities performed by ecclesiastical and monastic institutions, and the welfare provided by gilds and fraternities and individual benefactions as reflected in the acts of testators in their wills (McIntosh 1988, Bennett 1992, Harvey 1993).

To these concerns may be added the traditional medieval peasant 'poor law'; as it was first termed seventy years ago by Frances Page. Such a poor law was conventionally seen as having been based upon family arrangements by which, within the manorial courts, new tenants promised to the 'retired' or impoverished elderly peasant shelter in housing, food, clothing and fuel (Page 1930). Some historians have noted how great was the public dimension in these contracts, particularly in the late medieval demographic conditions when arrangements were made between persons who were frequently unrelated (Clark 1982, Smith 1991). This public involvement in welfare provision went beyond the curial monitoring of intra-familial and inter-personal maintenance agreements, since what was to become a fundamental element in early modern poor law, the common parish box, is known to have existed and is frequently mentioned in the wills of testators of the fifteenth century who left money or requested through 
'death bed land transfers' that land be sold specifically to raise funds for the poor, or for the payment of the king's taxes on behalf of fellow disadvantaged parishioners (Dyer 1994).

Given what appears to be a veritable 'mixed economy' of welfare prevailing before the events of the 1530s, when the early Tudor regime effectively 'nationalised' the church and its institutions that rendered charity, it is not surprising that what emerges as a result of a succession of legislative moves from 1536 onwards, culminating in the Elizabethan statutes of 1598 and 1601, should be regarded as so fundamentally different from prevailing practices in the later middle ages. Noteworthy in this respect are moves to fund welfare through a compulsory property tax, the 'centralization' (at the local parish level) of its administration being carried out through parish vestries and their unpaid officials working in conjunction with Justices of the Peace (JPs), as well as steps to punish vagrants and to put the able-bodied poor to work. The emerging focus upon the parish as the unit of welfare funding and administration is now so frequently singled out as not only differentiating early modern England from her European neighbours, but as also marking a very real break with earlier medieval practices in which the parish had a very minor role to play in the totality of welfare provisions (Slack 1988, Innes 1999).

We are fairly certain that parliamentary legislation was consistently using local models of welfare-provisioning that had been locally tested before the introduction of the 1598 and 1601 Acts. Indeed, it might be claimed that we have here a form of 'institutional path dependency' in the sense that parish-based revenue raising became 'locked in' as a mechanism for funding local welfare needs, although it could not have been so securely embedded without a strong central government or a state with responsive and reliable representatives or law officers resident in the localities, in the persons of the JPs. For instance, although statutorily separate, Tudor and Stuart dearth or famine policies (principally the 'Books of Orders', on which see Section 3, below) did much to remedy deficiencies in the social distribution of scarce grain in grain-producing areas (Slack 1980). It is also probable that the abandonment, particularly after 1630, of these interventions in favour of new practices aimed at increasing the cash in the hands of those whose vulnerability was exposed to high grain prices in bad years may have had beneficial commercial and economic consequences, effectively boosting the purchasing power of the poor (Slack 1992).

There has been much stimulating work on the parish, indeed the politics of the early modern parish has been promoted to a research theme of justifiable significance by Keith Wrightson and many of his pupils in recent years, and has rightly assumed a position as important as that of the politics of the county and the nation. ${ }^{2}$ This work has reminded us, in the elegant phrasing of Steve Hindle, that 'the early modern English parish, like all communities, had both margins and boundaries, and that becoming a member of, and belonging to, the parish community were transactions which entailed the negotiation of relativities of 
status and of space'. Indeed, as is frequently noted, the very existence of community also implies exclusion from membership (Hindle 2000: 97). Such a notion seems incontrovertible, yet it remains unclear how far developments from the late sixteenth century constituted a major redrafting of the criteria for community membership resulting from the central role assumed by the parish as a provider of relief to the poor.

There seems good reason to suppose that with the concentration of authority in the hands of parish officers that discretionary parochial relief provision was a noteworthy feature of day-to-day practice in the determination of welfare payments. There may have been a harder edge to the categorization of eligibility, as well as a growing desire by elites to associate poverty's causes with human failings in conjunction with a clearer identification of a tripartite classification of the poor into the impotent, the thriftless and the labouring poor. There is, too, a sense in the writings of early modernists that the English parish begins to acquire a stronger spatial sense of itself, of its boundaries and of its inhabitants who have entitlements - with entitlements to relief being a major concern. This is reflected supposedly in a growing fear of strangers and the 'unsettled' - a fear that culminates in the Settlement Laws of the late seventeenth century which codify this notion of attachment to place and its associated entitlements. There is much to be said for this approach, which interrogates the community by focusing as much on who was excluded as on who was an acknowledged member or insider.

However, to characterise such features of the local social structure as 'the unwelcoming, not to say the unwelcome, face of community' is to focus on only one side of the coin (Hindle 2000: 101). A system of welfare funding that was so heavily dependent upon revenue-raising from a local property tax would be obliged, particularly in a society in which geographical movement was so common an experience, to set rules regarding those individuals for whom local ratepayers assumed a responsibility for support. Welfare systems have never been universal in their reach. Entitlements have almost invariably been restricted by ruling that 'strangers' are not eligible for support. Indeed, according to Michael Walzer, welfare systems, as expressions of distributive justice, necessarily require hard lines to be drawn between insiders and strangers. As he puts it, 'the idea of distributive justice presupposes a bounded world of "citizenship" within which distribution takes place: within a group of people committed to dividing, exchanging and sharing social goals, first of all among themselves' (Walzer 1983: 31).

It might be helpful to introduce into this debate notions from collective action theory and from the perspective of the donor - the welfare funder as well as the welfare beneficiary. If not, we may be in danger of losing sight of how revenue for welfare purposes might be generated locally in adequate quantities to meet needs. Collective action theory would suggest that willingness to provide welfare funds would be forthcoming and persist only if one could trust one's peers, not just in one's parish of residence but in all other parishes to be equally 
forthcoming in their revenue raising. If welfare is provided in one parish and not in another the danger is that those in search of support will move to that parish in inordinate numbers allowing potential rate or taxpayers in other parishes to free-ride. Collective action theory takes it for granted that it is rational for a group member (i.e., in this case, a rate-payer) to want to enjoy the benefits of welfare provisioning for the poor without paying the costs, thereby creating the paradoxical situation that a good does not come into existence or functions only sub-optimally although its proper functioning is beneficial to all members of the group.

Mancur Olson provides the widely exploited theoretical framework for the importance of the free-rider problem in the resourcing of collective goods, since the non-excludability of the good implies that a member of a group profits, even if he or she makes no contribution to it (Olson 1965). Such a position takes it for granted that it is rational for a group member to want to enjoy the benefits of an arrangement without paying the costs. Abram de Swaan, in his In the Care of the State, has considered in rather generalised terms early modern European charity and welfare provisionings in these terms and sees the English Elizabethan poor law as one means by which the free-rider problem is effectively tackled. For de Swaan, the Poor Law of 1601 , by requiring the parish to levy an adequate poor rate from its property owners, enabled the replacement of an unstable preReformation local equilibrium of voluntary collective charity by a system of obligatory taxation (de Swaan 1988: 21-36). Thereby the task of collection, Coordination and disbursement is shifted from voluntary church agencies to appointed or elected overseers of the poor and, more importantly, the care of persons without means of subsistence was assigned to their community of legal 'settlement'. By conceptualising the problem in these terms it becomes easier to see how the increasing formalisation of the subsequent Settlement Laws, which accompanied and buttressed the Poor Laws and the sustained growth in the sums raised and dispensed (even though real incomes were rising in the century after 1650), were intimately interconnected and mutually reinforcing developments (Slack 1990: 45-58, Smith 1996).

The law of settlement and removal introduced in 1662 definitively removed any idea that paupers had a secure claim to relief simply on the basis of residence in a parish (although it is doubtful whether such a right ever existed). However, England was in possession of a particularly mobile population, as anyone who has ever attempted to undertake nominative linkage of individuals appearing in a parish register will testify. Rarely do 50 percent of those born in an early modern English parish go on to marry and or die in that same parish. This feature of the social structure further highlights the need for a welfare system based upon more than 10,000 separate funding units to have rules relating to placebased entitlements to relief.

The law that dealt with these matters was not a single piece of legislation, but a complex collection of statutes and legal precedents. Two provisions constituted 
the root of the 1662 legislation. First, anyone able to rent a tenement for $£ 10$ per annum was exempt from its provisions and all those who were unable to meet those conditions had to reside in a parish for forty days or more to acquire a 'settlement' (right to poor relief) there. This was not easy, since to gain a settlement a migrant had to give notice in writing of his or her arrival and this in turn had to be read in church and entered into the Poor Law account book of the parish.

Such a procedure made it easy for objections to be raised. By the beginning of the eighteenth century there were various routes through which migrants were able to establish a new entitlement to relief that over-rode the forty-day rule. A settlement could be obtained by someone being hired for and fulfilling one year's service, and upon marriage a wife acquired her husband's settlement. Apprenticeship, service and marriage were contracts to which the Poor Law remained subservient. Likewise, anyone living on their own freehold acquired a settlement and those performing a parochial office automatically gained a settlement. Those who had not acquired a settlement in this way were at risk of removal if they were suspected of needing relief prior to 1795. But even in this respect the force of the law was mitigated somewhat by various measures. For instance, departing migrants could obtain certificates from the parochial officials in the parish where they were legally settled, recognising that parish's obligation to provide relief if they were to become chargeable elsewhere. A significant amount of non-resident relief was moved across space from parish to parish, and was a means by which urban parishes maintained relatively low expenditure, notwithstanding the presence in them of recent migrants lacking a local settlement (this is discussed in greater depth in section 2 below).

At the heart of many of the difficulties arising from this system was the small size of the parish unit as a source of and dispenser of welfare funds. ${ }^{4}$ Welfare theory provides a powerful argument that small demographic units of welfare provisioning based upon local revenue raising may be particularly susceptible to problems that stem from risk covariance. The theory is that 'insurance' is generally most efficiently supplied if the income of the person being insured is not positively correlated with the income of those providing the insurance. Thus if a community falls on bad times it should look for support from outside the community. Obviously, had early modern English poor relief been provided in geographical units larger than the parish an incentive problem associated with risk covariance may have been reduced and attitudes towards in-comers and the 'unsettled' may have been less fraught (Newbery 1989, Platteau 1991). However, as the units of risk-pooling increase in size problems associated with the elicitation of accurate information about the needs of potential beneficiaries become greater, and the willingness to contribute to the welfare fund on the part of the property holders may diminish. The small size of most parochial communities may have helped in the elicitation of information about individual needs, reducing but not eradicating the adverse selection effects that bedevil social 
security systems, although leaving beneficiaries susceptible to the discriminatory actions on the part of parish officers. ${ }^{5}$

\section{The agrarian roots of English poor relief in comparative context}

A note worthy feature of historians' work on early modern English poor relief in the period during which Parliament strove to establish the laws embodied in the later Tudor statutes of 1598 and 1601 is that they possessed a decided urban emphasis or preoccupation. In fact, the notion that poverty and the procedures for tackling it were heavily focused on towns gave to the literature on early modern England an attribute which it certainly shared with the early modern European historiography of poverty and welfare (Slack 1988, Warde 2007). However, where the English historiographical tradition diverged from that of much of Europe was that by the eighteenth century and especially its latter half, the emphasis was much more heavily directed to poverty as a rural problem and deeply rooted in the functioning of the agrarian economy. ${ }^{6}$ In contrast, considerations of poverty in much of eighteenth-century Europe retained an urbancentric emphasis that suggested a continuity of concepts and sources with the European situation two centuries earlier.

A particularly suggestive indication of this distinctively rural 'tradition' of thinking and emphasis can be identified as early as 1792 in the Annals of Agriculture (Howlett 1792). In that year, Arthur Young had brought the reports of the French Committee of Mendicity that had appeared over 1790-91 to the attention of John Howlett, that astute contemporary observer of eighteenth-century English poor relief practices, enclosure and population (to name but a few of his interests). Those involved in France in the drafting of these committee reports were of course much interested in procedures relating to poor relief as practised in England, and it had been noted with incredulity by contemporary French commentators that Howlett himself had reported that 'the number of our poor occasionally relieved are frequently a third part of the total of paupers assisted'. Furthermore, they had observed that it was reported that in a certain parish fifty or sixty miles from London are annually no less than a third of its total population [relieved] and that, extraordinary cases excepted, the proportional number of poor is greater in country parishes than in manufacturing towns'. French expectations were clearly that rural areas would have few relief recipients and that towns, particularly those with industry, would expend more resources in relief and higher proportions of their populations would be recipients there than in rural areas.

It is commonplace to stress that in seventeenth- and eighteenth-century France, unlike England, revenue for poor relief was in general not raised by compulsory rating or taxation. Many villages and towns had so-called bureaux de charité which were a pool of alms primarily from voluntary (albeit very diffuse) sources, which did provide outdoor relief, often in case or kind. But this 
Table 3.2 Howlet's evidence on the urban-rural differential in the Poor Law's financial incidence (ratio of each $£$ raised per head of population)

\begin{tabular}{|c|c|c|c|}
\hline & $\begin{array}{c}\text { No. of } \\
\text { inhabitants }\end{array}$ & Poor's rate & $\begin{array}{l}\text { Proportion of } £ \\
\text { to inhabitants }\end{array}$ \\
\hline $\begin{array}{l}\text { Nine towns, chiefly } \\
\text { manufacturing of the greatest } \\
\text { magnitude in this kingdom, } \\
\text { that is Norwich, Manchester, } \\
\text { Birmingham, Bristol, Sheffield, } \\
\text { Exeter, Worcester, Leeds and } \\
\text { Nottingham }\end{array}$ & 193,158 & 49,296 & about 1 to $6 *$ \\
\hline $\begin{array}{l}67 \text { towns of inferior, none of } \\
\text { them containing } 10,000\end{array}$ & 130,000 & 36,844 & 1 to $3 \frac{1}{4}(3.25)$ \\
\hline 320 county parishes & 139,000 & 53,413 & 1 to $2 \%(2.6)$ \\
\hline
\end{tabular}

* In the cities of London and Westminster and borough of Southwark, the proportion is nearly the same

Source: Howlett (1792)

provision was supplemented and often surpassed in absolute amounts in the largest towns by the more ambitious and certainly more ostentatious hôpital general as an institution for the employment of the idle, relief of the sick and orphaned and the punishment of the rogue or vagrant. To these providers of welfare we should add the Hôtel-Dieu, an older institution theoretically serving the sick poor and primarily, indeed almost exclusively, urban-located. It embodied certain attributes of the English workhouse or house of correction but did much more besides and usually contained in excess of 100, and in the larger provincial centres could house over 1,000 inmates. ${ }^{7}$ In France, the most striking embodiment of formal relief was the large urban-located institution; in England, it was the parish-based rate that was collected in both town and countryside with equal efficacy and, as Table 3.2 shows, in the late eighteenth century, Howlett provided evidence to show that it was siphoned off with a higher intensity in rural than in urban settings, with a pound raised per 2.6 inhabitiants in 320 county parishes, as against one pound per 6 inhabitants in nine large towns. ${ }^{8}$

It cannot be stressed too greatly that in France the resources in theory available for outdoor relief through bureaux de charité seem in practice to have been somewhat limited. In fact, these funds, when available, tended inexorably to gravitate to towns. Ecclesiastical tithe, for instance, usually hovering around onetwentieth of gross agricultural product, was frequently carried off to swell the store-houses of church dignitaries in the diocesan capitals, and so served as an urban levy on the countryside. The tendency for the nobility and haute bourgeoisie 
to be urban domiciled exacerbated the urban-focused character assumed by charitable funds.

The Committee of Mendicity surveyed each French département's total resources supposedly available for the provision of outdoor relief. Assuming, as did Olwen Hufton (1974) when she pioneered consideration of this source, that around 25 percent of the population was in need of welfare support, then the real extent of resources available to meet that need, and revealed by the Committee's work, was evidently not very great. If allowance is made for the possibility that approximately 30-40 livres might meet the bread grain requirements for one individual over the course of the year, then some simple calculations can be made relating to the relief potential provided by these welfare funds across regions. In the wealthiest départments (Seine-Inférieure, Flandre, Meuse, Cote-d'Or, Bouche-du-Rhone and Loiret.), so distinguished on the basis of their available charitable funds, 1-4 livres per capita for the poor, or the equivalent of 10-40 days of bread, could be provided annually. Worse than this, in the geog-raphically extensive belt running from the Basses-Pyrénénees through Gascony, the Landes, Gironde, Lot-et-Garenne, and Lot through the Dordogne, Charenter and the Corèze to the Creuse and Puy-de-Dôme, the total resources divided by the 25 percent assumed to have been in need would have been sufficient in any one year to buy a single pound of bread for each hungry person. These figures, even if exaggerated regarding the inadequacy of the support available, are striking in what they reveal when set against the rate-based relief in England, which in the mid-1780s was capable of supporting, primarily in the form of outdoor relief, 10 percent of the total population in bread for the whole of any calendar year. ${ }^{9}$

The extent to which the later seventeenth- and eighteenth-century Poor Law in England offered aid in the form of outdoor relief might at first glance seem surprising, given that the Elizabethan statutes which provided the legal foundations on which the system of parochial relief rested stressed four main functions, of which only one involved substantial expenditure on people in their own homes. These were (i) to relieve in almshouses those unable to work - old, sick and disabled persons, (ii) to provide work for those unable to find work but who were able-bodied, (iii) to apprentice children by redistributing them into households so situated that they could put them to work profitably, and (iv) to assist those who found themselves in 'family circumstances' that made them incapable of being self-supporting. By some considerable margin, the emphasis on the Elizabethan legislation as it had progressed from the 1550s was on the first and second functions - indoor relief and work provision. These were very familiar themes in pan-European welfare aims and practices at the time and in no sense distinguished England from her continental neighbours. Furthermore, the significant physical size of indoor institutions combined with punitive measures to deal with vagrants and the quasi-disciplinary attempts to give the unemployed work were particularly prominent features of the markedly urban-oriented settings of welfare provisioning in the sixteenth century. This is not surprising in 
so far in an English context it was the towns that had lost most in terms of institutional support for the poor as a result of the changes brought about in the 1530 s. $^{10}$

To focus on outdoor relief without reference to the Tudor and early Stuart dearth or famine policies would be to tell only part of a far more complex story. There is not space to delve deeply into this matter, but it might be worth stressing the significance of the shift in dearth policy or practice after 1630 that Slack (1988) was perhaps the first to signify. The interventionist stances that had been crystallised in part through the Books of Orders moved more directly to one in which, rather than intervening in the market to requisition grain and to limit its free movement in periods of shortage, greater reliance was placed upon putting cash in the pockets of the poor to enable them to buy grain or bread. This was most definitely enabled by and possibly a contributor to the spread of rate-raising and the use of rate-based revenues for the provisioning of outdoor relief. It was in such processes that the spread of rate-based revenue to rural settings acquired momentum and that in part helps to explain how the situation we observe so much more clearly in the eighteenth century had come into being. ${ }^{11}$

In introducing this discussion, use has been made of John Howlett's comments on urban-rural contrasts. It is worth stressing how London and Middlesex stand out as a welfare 'desert' when funds derived from the rates are concerned, a feature that would add greatly to the disbelief of those French commentators from the early 1790s. There may be a mixture of explanations for this feature of poor relief geography. Low per capita expenditure might well reflect the large quantities of alternative charitable resources in London (although crowding-out effects in the relationship between rate-based and voluntary charitable expenditure are generally not a feature of welfare funding in early modern England); London's more diverse economy would have provided a multitude of opportunities to generate incomes; London would, unlike the nation in general, have had a population with a far higher proportion of its population between fifteen and thirty-five - the age groups least likely to be deemed eligible recipients of relief. ${ }^{12}$

Many long-stay migrants would also have lacked a settlement in the city but would have been eligible for support from rural areas from which they had migrated. In fact, the evidence assembled by Sokoll (2001) relating to the early nineteenth-century pauper letters written by those who were resident extraparochially suggest a strong propensity for those settled in rural and markettown Essex to have relief sent from those rustic settings to support them in their London residences. ${ }^{13}$ Non-resident relief is a subject that is greatly in need of more thorough-going quantitative research, since it may be another factor at a broader inter-regional level that might account for lower expenditure in the northern urban and industrial regions in the eighteenth century. It is also another indicator of how far welfare revenue raising was so heavily grounded in the rural economy and the agrarian sector, and perhaps another reason for reflecting 
further on the large charge placed upon this sector in underpinning social and economic change over the two centuries prior to 1850. This was a charge that the French rural economy could not meet and perhaps would not have been required to carry, given the dominance of the peasant farmer as opposed to journalier households in the majority of French regions.

\section{Parochial relief practices and epidemiological consequences in England c.1650-c.1800: some further comparisons}

In this section of the chapter the focus is primarily on certain features of English and French mortality and epidemiological history in the seventeenth and eighteenth centuries that may be set against the background of welfare practices in those two historical settings. In what follows, the preoccupation is principally with possible demographic patterns that flow from the differences in the relative shares of relief that are provided in 'indoor' and 'outdoor' forms in different contexts and the quantities of welfare funding available per capita in town and country. In particular, the focus is placed upon the role of the small parish unit as the administrative context within which funds were raised and disbursed in England and the absence of such frameworks and practices in France.

In specifying 'indoor' and 'outdoor' relief, a distinction is being made in fairly generalised (some might claim crude) terms between relief given as income substitutes or supplements to persons who did not live within the confines of larger institutions such as hospitals, workhouses or houses of corrections, and that given in the form of care, cash allowances and medical services to persons lodged within such institutions. Consequently, indoor relief is regarded as that which is obtained by persons on, or as a consequence of, entering such institutions. It must be acknowledged at the outset that one cannot be too categorical in the use of these terms in so far as they were far from being 'noncommunicating' sectors of welfare provisioning. Certainly, continental European hospitals did give outdoor relief, although it proved to be an area of their overall activity that is difficult to quantify; where it has been studied, the focus has almost invariably been upon fairly substantial urban centres in which a minority of the total populations resided (Jutte 1994, Henderson 2006). However, the principal purpose here is to attempt to relate these welfare systems to the demographic and more specifically, the epidemiological regimes in which they were embedded. I would argue that it is the relative share of welfare in the respective sectors that is the key issue in so far as that distribution has considerable bearing upon both the way welfare was managed and the extent to which it reached those in need of assistance.

It is noteworthy how quickly use of indoor relief and its associated institutions - almshouses, hospitals, bridewells, houses of correction - became restricted elements in relief provision after c.1630 relative to the provision of outdoor relief in the form of cash payments to persons in their own homes. 
Another integral part of early modern English welfare provisioning, although statutorily separate, was the Tudor and early Stuart dearth or famine policy which was embodied in the Books of Orders, specifying a set of actions to be implemented in the event of harvest difficulties, food shortages and high prices (Slack 1980). The key practices concerned government measures to ensure that, in times of dearth, corn supplies were to be kept in the country, carefully husbanded and distributed to those in need. These measures involved prohibition of grain exports when prices were high, public purchases of corn from abroad, and searches and surveys of corn supplies undertaken by public authorities with a view to a regular and ordered provision of the open market. In practice, the policy of searches and market provision did more to remedy deficiencies in the social distribution of scarce grain in grain-producing areas than deficiencies in its geographical distribution, reflected in the continued vulnerability of the northern and north-western regions of England to famine well into the third or fourth decades of the seventeenth century when most of the remainder of the country was not so affected (Appleby 1978).

Nonetheless, it was certainly a dearth policy that encouraged a sense of social responsibility among JPs, who were increasingly expected to act by the general populace in the public interest. These same local men who were also agents of central government were simultaneously charged with monitoring the machinery for the implementation of a parish rate-funded relief (Walter and Wrightson 1976). As previously noted, it was after 1630 that the 'dearth policy' was altered as with a growth in relief practices financed from parish rates, strenuous efforts were made to expand the quantity of cash in the hands of those whose vulnerability was exposed to high prices in dearth years. On any scale of rating of public action and early responsiveness in the face of famine threats, English Tudor and especially early Stuart governments, both centrally and locally, would score highly. Central governments were well informed in large measure because of the effective integration of parishes into the national administrative centre through the speedy reactions of the JPs - those outwardly orientated, although provincially, indeed parochially domiciled, unpaid 'workhorses'. They, more than any other agency, came to determine a pattern of poor relief which was largely rendered in the form of cash placed in people's pockets. The move towards widespread raising of parish rates to fund these cash payments was by no means instantaneous.

Of course, the cash relief provided from the rate-based welfare funds rather than food aid per se may have been decidedly problematic. As Drèze and Sen remind us, cash aid can almost always help an individual to acquire food and avoid starvation (Drèze and Sen 1991). It is less clear, however, whether such practices are always good for collective security, in so far as one person's capacity to obtain food through cash can adversely affect the entitlements of others by placing an upward pressure on prices. Nonetheless, in the early modern English case, this potential outcome seems largely to have been avoided, since the 
enhanced purchasing power so provided appears to have stimulated interregional trade, effective grain storage and overall agricultural productivity. Wrigley has reminded us that even Malthus, who is generally perceived to be no friend of 'transfer incomes', had seen - in his neglected essay entitled An investigation of the cause of the present high price of provisions, published in 1800 - the beneficial impact of income subsidies in dearth years in very similar terms in his diagnosis of different outcomes following from severe dearth conditions in England and Sweden in the late 1790s. T.R. Malthus judged the English case far more favourably both in economic and demographic terms, notwithstanding the fact that less severe physical shortfalls of grain had provoked much higher price rises, in part because of the impact of wage subsidies which he saw as sustaining demand. In England there was no mortality surge but in Sweden death rates rose sharply (Wrigley 1999).

What emerges as the striking feature of the Old Poor Law in England is that monetary relief was given in substantial quantities both to the impotent, especially elderly poor, and to those indubitably able-bodied, most commonly young widows or women deserted by their husbands and left with young children. This relief was allocated to parishioners primarily in their own homes. In addition, in the last half of the eighteenth century (although with considerable variation from place to place), able-bodied male heads of household increasingly received monetary relief in growing quantities (Slack 1992). This was provided when a combination of difficult economic conditions such as arose through bad weather, high prices or slack seasonal labour demand, and the claims of more dependants than such male (frequently the sole income-providers in rural economies) could cater for, drove them to desperation. Such a set of welfare-provisioning characteristics came about, notwithstanding the 1722 Workhouse Act which had sought to check applications for relief from the ablebodied by making entry into the workhouse a condition of receiving relief. While workhouses were built (which in the terms of this present discussion, may be categorized as indoor relief) they were to be found in only 15 or 16 percent of the English parishes by 1773 and few of those parishes apparently applied the workhouse test (Slack 1990: 31-3).

In 1802-03, the first date for which we can undertake such a calculation, about 75 percent of the Poor Law Bill of c. $£ 4,000,000$ was spent on outdoor relief. Of the marginally more than 1,000,000 persons (approximately 11 percent of the population) receiving relief that year, 93 percent were relieved outdoors. While this almost certainly represents the pauperization of a larger proportion of the able-bodied population than applied a century earlier, it would seem that no fundamental change of practice had occurred. Evidence from the Board of Trade returns for 1696 suggests that relief, largely of the outdoor kind, was available at the level of about $£ 75$ per annum for every 1,000 of the population or alternatively would at the prices then current have supplied about 5 percent of the population with basic food requirements for the whole of a year. 
In 1696 the value of parish charities, which also largely took the form of outdoor relief, was considerable and therefore would have to be added to the revenue raised by the parish rate. In what are justifiably considered to be controversial assessments (Slack 1990: Table 1, 22), Jordan (1959) estimated that in 1660 the total income from charities was c.£100,000, roughly the same, perhaps, as the income from poor rates at that date. ${ }^{14}$ The number of charitable trusts probably doubled in the next century and a parliamentary enquiry estimated their income in 1788 at $£ 258,700$ (the returns are known to be incomplete). Paul Slack has recently gone so far as to suggest that in the 1780s (before the huge rise in ratebased poor-relief expenditure took place) income from charities was contributing as much as the rates and in the towns with hospitals and subscriptions, charity may have been the dominant partner alongside rate-based income, although it too made considerable contributions to outdoor relief (Slack 1990: $41-4) .^{15}$

In section 2 we have already drawn some comparisons with the situation in France and commented on the patterns evident in the data collected by the postrevolutionary Committee of Mendicity. Additional evidence is also revealing. In a detailed, highly relevant case study, Colin Jones has considered this same body of evidence and finds in 332 communities in the Montpellier region - containing 250,000 to 275,000 persons - that 150 (or 46 percent) had no forms of relief whatsoever. Jones is also able to estimate, albeit in a highly approximate fashion, the amounts of home relief available; 162 communities had nothing to dispense and 73 had less than 49 livres to distribute. Indeed, 72 percent of the 332 communities had either no relief or at best could support just one person for one year (Jones 1982). Such evidence is entirely consistent with the expectations of those French commentators who found Howlett's observations so hard to believe regarding the relative relief expenditure levels in town and country in England.

In what follows, attention is directed to certain demographic implications of this uneven and thin spread of charitable resources in France, in particular, their tendency to concentrate in the towns. Take, first of all, the substantial sums expended on eighteenth-century English single-parent, female-headed households in general. Such transfers from collectivity to households or individuals were far less likely in France at a comparable point in time. One obvious concomitant of this was the tendency of both unmarried mothers and fatherless households to drift into towns or to jettison their marginal, insupportable, and in some cases, unwanted offspring in urban centres. While this matter could be assessed in far greater detail, for the purposes of this present discussion it is necessary only to sketch certain demographic patterns concerning illegitimacy that are highly characteristic of eighteenth-century French society.

In the second half of the eighteenth century it was not at all uncommon to find French urban and rural illegitimacy ratios that differed by a factor of ten to twenty. For example, Jean-Pierre Bardet's study of Rouen shows the illegitimacy 
ratio in the city (Bardet 1983: 337) to have been around 20 percent while in the surrounding Normandy countryside it was less than 2 percent. Bardet's estimates, partially based on the déclarations de grosesse illégitimes, suggest that over 70 percent of those births in Rouen concerned girls who had come into the city or were recent immigrants. The link between this form of behaviour and the exposure of the newborn is, of course, well known and in this matter, Rouen is no exception; in 1710 , foundlings left with Rouen's Hôpital Général displayed a death rate of 580 per 1000 , rising over the subsequent seventy years to the sickening heights of 916 per 1000 in 1780. Rates of foundling mortality varying from 600 to 900 per 1000 are the norm in French urban communities throughout the eighteenth and early nineteenth centuries.

The concentration of very large numbers of domestically insupportable infants and children within these overcrowded hospital premises had obvious repercussions for their well-being. Jones' study of the Hôpitaux Généraux in Montpellier and Nîmes shows how infants spent their early months with wet nurses, but wet nurses who were for the most part some seventy kilometres distant from the towns and resident within the impoverished welfare 'deserts' that were the villages of the Cévennes, the uplands forming the south-eastern fringe of the Massif Central. In part, this great distance was caused by the fact that wet nurses in the immediate surroundings of these two southern French towns were hired by the town's elite and were in receipt of wages that were three to four times greater than those accepted by their Cévenol equivalents. In 1779 an inquiry revealed that out of 610 children sent into the Cévennes in the period from 1767-77, 71 percent had died prior to the date of their scheduled return (Jones 1982: 106-7). These figures would be swollen considerably if accurate data were available on the deaths occurring in the hospital prior to the journey to the mountain villages. While it would be simplistic in the extreme to see such patterns as solely to do with the relative supplies of outdoor and indoor relief in country and town, the contrasts with England are revealing. ${ }^{16}$

Outdoor relief in England seems to have been much more consistently and overtly employed to uphold the independence of the household in situ whereas the French urban-based institutions provided more restricted domestic support or in the case of the foundling and its mother, offered a highly dangerous alternative to the family or household environment. ${ }^{17}$ Welfare, in the form of cash payments, fuel allowances and rent subsidies given in England to people in their homes may have proved to be a more effective way of maintaining relatively low levels of infant and child mortality than was achieved in the majority of French regions. In France we can observe the practice of irregular, unpredictable and certainly inadequate shows of gift-giving to rather small numbers of people or the transfer of infants from the less hazardous rural to the more hazardous urban environments in which the hospitals were located. From such institutions the foundlings were sent into the problematic care of their impoverished wet nurses serving further to reduce their survivorship chances. Such features of welfare 
provision were characteristic practices in sizeable regions of eighteenth-century France.

By contrast, a more predictable and relatively generous level of outdoor relief to mother and infant offspring may indirectly have increased the fertilityreducing effects of breastfeeding that was surprisingly ubiquitous in English villages and small towns, by improving infant survival prospects and by lengthening the post-partum non-susceptible period that is noteworthy at twelve to fourteen months for being comparatively much longer in England than in many, although not all parts of France (Wilson 1986). While the regional differences in breastfeeding in both France and other parts of continental Europe are in need of explanations that have to do with complex cultural histories, it is far too simpleminded to equate areas of low infant mortality with areas that show such feeding practices to be ubiquitous, for there were many rural areas in which breastfeeding was the norm but in which infant mortality rates far exceeded 200 or 250 per $1000 .^{18}$

The child mortality rates are commensurately higher in the French parish data sets and the contrast between the two 'national' experiences emerges strikingly when survivors to exact age ten are considered in the two populations; for every 1000 individuals born in early eighteenth-century England, 700-725 survived to age ten whereas in France only 500 of the original cohort of 1000 would live. Even in the most favourable French region, the south-west, the survival rate to age ten was 580. Mortality rates from the rural parishes of Devon which are among the most favoured communities with regard to their life expectancy so far analysed would suggest that they experienced levels of survival rates to age ten in the seventeenth and eighteenth centuries in excess of $800 .{ }^{19}$

The welfare practices of the English Old Poor Law and its associated institutions, narrowed down the obligations that individuals owed to their wider kin, enabling the parental generation within the simple family household to enlarge pari passu its capacity to help, care and offer guidance to the infant and young child. One obvious area of restricted kin support consequent upon communal care provision is that provided by the lineal family to the elderly (Smith 1984, Laslett 1988, Smith 1998). While not denying a significant amount of intrafamilial care, the parish in rural England played a key role, consequently diminishing the obligation heaped upon married children who might at that very phase when assistance to elderly parents was needed, have dependent children and infants of their own. The long birth interval-breastfeeding-low infant mortality areas (with infant mortality rates $100-150$ per 1000) may be in certain circumstances reflecting the consequences of injections of income subsidies into household economies that ensured the survival of both mother and child. The limited family provision for the elderly, the departure from their natal hearth of older children as parochially funded servants-in-husbandry or as pauper apprentices contracted to work or placed by Poor Law officers in the households of nonkin may have been other additional influences reducing pressures on English 
household economies with tangible benefits accruing to the youngest dependants (Wrigley 1987a: Table 7.7).

It would seem that a good deal of the outdoor relief provided through the English Old Poor Law was concerned with remedying income losses brought on by contingencies such as sickness, death, decrepitude, indeed ameliorating a fall in living standards at times of relative scarcity. The identification of likely beneficiaries of such a system does not have to be in the form of strict means-testing or income-testing. Regular life-cycle contingencies, such as maternity, sickness, disability, unemployment and old age, can be used as fairly straightforward tests of the probability of being in need. The effectiveness of this type of system depends, as Tony Atkinson and John Hills note, on the extent to which those covered by these contingencies are the poor in a society (Atkinson and Hills 1991). It also depends on the administrative costs of identifying entitlement to what might be regarded as 'categorical' benefits. The administrative problem that such a system is obliged to solve are not to be underestimated and above all concern the elicitation of the correct information concerning who has fallen into the relevant categories. It might be proposed that the English Old Poor Law, especially in the agricultural regions of southern Britain, was reasonably successful in eliciting appropriate information and rendering the effective reactions. Both cash subsidies and the provision of grain through systems of communally administered and funded welfare - along with an administrative machinery that intervened in grain markets to minimize the dislocational effects of variable harvest quality - all helped to minimize short-term rises in mortality in periods of inflated food prices.

In section 1 we noted that Galloway found that 46 percent of the fluctuations of deaths over age five in France in the period 1677-1734 were associated with fluctuations in grain prices. ${ }^{20}$ In England from 1675-1755 the comparable figure was only 24 percent; in France the response in the year of high prices and that following were 30 and 29 percent respectively, whereas in England the comparable percentages were only 11 and 19. Furthermore, Galloway discovered that in France and not in England runs of years of high prices had an extra effect in raising mortality (Galloway 1981). Somehow it does seem that the propertied classes in early modern England solved the problem of collective action with regard to their dealings with the poor by their administration of a system of regular rate-based relief and irregular but very necessary voluntary redistributions that depended on the vast majority of benefactors trusting that their peers would do likewise.

One suspects in this respect that English systems, unlike those in France, were only minimally bedevilled by the free-rider problem where the generation of reasonably adequate welfare funds was concerned. Such success did, however, depend on a particular kind of face-to-face relationship between benefactor and beneficiary. In some senses the system most likely limited the frantic town-ward migration of impoverished families in periods of dearth, if not of adolescents and 
young adults who were not yet 'settled' or who were not deemed to a deserving age category. It may have indirectly limited the extent to which disease was spread during periods of crisis. Such an interpretation is sustainable, notwithstanding some suggestive findings from John Landers and Patrick Galloway that London may have attracted during years of dearth in the late seventeenth and eighteenth centuries increased numbers of persons in the age groups 15-24, who may in terms of the 'welfare-beneficiary' model to which we referred earlier, not have been deemed socially acceptable beneficiaries of poor relief in rural communities but perished as urban immigrants who were exposed to diseases to which they had no acquired immunity - smallpox is the most obvious cause of death impacting upon this group (Galloway 1985, Landers 1993: $115-40) .^{21}$

A comparable effect has also been identified by Patrick Galloway working on eighteenth-century Rouen where high food prices were associated with mortality surges in the town but not in rural areas. What is more, the mortality surges in Rouen were equally characteristic of all social classes, suggesting that hunger per se was not the proximate cause of death. The preferred interpretation of this pattern is that social mechanisms designed to reduce hunger among urban populations, such as price controls and the distribution of grain to the poor which did not operate in rural districts could induce mortality surges if starving people of all ages flooded into the urban centres from the countryside bearing disease with them rather than becoming exposed for the first time to those diseases endemic within the towns on their arrival (Galloway 1986).

\section{Conclusion}

Can we go so far as Ron Lesthaeghe and claim that the extent of risk-sharing across both social class boundaries, economic sectors and across regions are a good measure of a society's social and political integration and that a high degree of such integration corresponds with a greater preponderance of 'preventive checks' over 'positive checks' in the demographic system (Lesthaeghe 1980)? In so far as the system of welfare such as that produced by the English Old Poor Law was one that ensured that the effects of the demographic actions of individuals would be spread over politically constituted parish units, Lesthaeghe is correct in his judgement. This issue is of broader significance since in making sense of the character of the early modern English demographic regime it is vital to be cognisant of the fact that the purchase which fertility had on the demographic growth rate depended heavily on the underlying high rates of survivorship that held throughout the whole of the early modern period, not withstanding the tendency of life expectancy to go through a long cycle of deterioration and improvement. ${ }^{22}$

Similarly, did the face-to-face nature of the relationships between the ratepayer, the welfare administrator or overseer who might himself or his family 
one day be a recipient of welfare and the welfare beneficiary, create the cohesiveness to which Lesthaeghe refers? If it was achieved, was it only effectively secured in highly specific regional contexts and was it anchored by means that infringed personal liberties with adverse equity implications? Some might respond that the parochial framework which in the vast majority of cases involved relatively small populations facilitated a close face-to-face relationship between overseer of the poor and beneficiary thereby helping to minimize, if not to eradicate, the adverse selection effect that bedevils social security systems. Furthermore, the smallgroup context created by the parish within which the bulk of relief was provided may have served to reduce many of the transaction costs associated with administration and information that are frequently assumed to create incentive problems that worked against the successful implementation of welfare schemes in pre-industrial settings. In modest-sized parochial units the costs of information collection, contract enforcement and entitlement awareness may have been reduced to manageable levels.

Abram de Swaan viewed the English Old Poor Law as having secured a favourable resolution of the problems of risk-covariance and free-riding through imposing a strong dose of central control (de Swaan 1988: 37-41). Undoubtedly a powerful state would seem to be a necessary condition, but so is an equally vibrant and functionally effective local community in the form of the parish along with a relatively muted role for the wider kin group as a welfare provider. This chapter, given the constraints of space, has devoted insufficient attention to the roles played by a host of voluntary and formally corporate institutions that complemented the Old Poor Law in the provision of welfare and which unambiguously linked early modern England with many of her European neighbours. However, as Paul Slack reminds us in the conclusion of his Ford Lectures, in the case of early modern England we have an intriguing paradox since 'England seems to have been able more easily than other countries to enjoy the benefits of both a flourishing corporate and voluntary sector and a powerful central authority and legal system, without the second smothering the first' (Slack 1998: 161). In fact, Slack regards the Old Poor Law as 'the most striking example of the state and the community interacting creatively without one crowding out the other'. The crowding in that this enabled, it might be suggested, had significant advantages for early modern England in generating more resource redistribution across classes and between agrarian and industrial sectors as well as enhancing demographic survivorship probabilities which were an important pre-requisite in enabling the variable operation of the preventive check to have had so much of a purchase on English population growth rates, especially after 1650 . 


\section{References}

Adams, Thomas (1990). Bureaucrats and Beggars: French Social Policy in the Age of the Enlightenment, New York: Oxford University Press

Appleby, Andrew (1978). Famine in Tudor and Stuart England, Liverpool: Liverpool University Press

Atkinson, Tony and John Hills (1991). 'Social security in developed countries: are there any lessons for developing countries?', in Ehtisham Ahmad, Jean Drèze, John Hills and Amartya Sen (eds) Social Security in Developing Countries, Oxford: Clarendon Press

Bardet, Jean-Pierre (1983). Rouen aux XVII et XVIII siècles: Les mutations d'un espasce social, Paris: SEDES

Bennett, Judith (1992). 'Conviviality and charity in medieval and early modern England', Past and Present 134: 19-41

Clark, Elaine (1982). 'Some aspects of social security in medieval England', Journal of Family History 7: 307-20

de Swaan, Abram (1988). In Care of the State: Health Care, Education andWelfare in Europe and the USA in the Modern Era, Cambridge: Polity Press

Deane, Phyllis and W. A. Cole (1969). British Economic Growth, 1688-1959, 2nd edition, Cambridge: Cambridge University Press

Drèze, Jean and Amartya Sen (1991). 'Public action for social security: foundations and strategy', in Ehtisham Ahmad, Jean Drèze, John Hills and Amartya Sen (eds) Social Security in Developing Countries, Oxford: Clarendon Press, pp. 1-40

Dyer, Christopher (1994). 'The English medieval village community and its decline', Journal of British Studies 33: 407-20

Dyer, Christopher (1998). 'Did the peasants really starve in medieval England?' in Martha Carlin and Joel Rosenthal (eds) Food and Eating in Medieval Europe, London: Hambledon Press, pp. 53-72

Eastwood, David (1994). Governing Rural England: Tradition and Transformation in local Government, 1780-1840, Oxford: Clarendon Press

Feldman, David (2003). 'Migrants, immigrants and welfare from the Old Poor law to the Welfare State', Transactions of the Royal Historical Society (6th ser.), 13: 79-104

Galloway, Patrick (1981). 'Basic patterns in annual variations in fertility, nuptiality, mortality and prices in pre-industrial Europe', Population Studies 42(2): 278-304

Galloway, Patrick (1985). 'Annual variations in death by age, deaths by cause, prices and weather in London 1670-1830’, Population Studies 39(3): 487-505

Galloway, Patrick (1986). 'Differentials in demographic responses to annual price variations in pre-revolutionary France; a comparison of rich and poor areas in Rouen, 1680-1787', European Journal of Population 2(3/4): 269-305

Griffiths, Paul, Adam Fox and Steve Hindle (eds.) (1996). The Experience of Authority in Early Modern England, London: Macmillan

Hadwin, J.F. (1978). 'Deflating philanthropy', Economic History Review 31(1): 105-117

Harvey, Barbara (1993). Living and Dying in England 1100-1540, Oxford: Clarendon Press

Henderson, John (2006). The Renaissance Hospital: Healing the Body and Healing the Soul, New Haven $\mathrm{CT}$ and London: Yale University Press

Hindle, Steve (2000). 'A sense of place? Becoming and belonging in the rural parish 1550-1650', in Alexandra Shepard and Phil Withington (eds) Communities in Early Modern England, Manchester: Manchester University Press, pp. 96-114

Hindle, Steve (2004). On the Parish: The Micro-Politics of Parish Relief in England, 1550-1750, Oxford: Clarendon Press

Houdaille, Jacques (1984). 'La mortalité des enfants dans la France rurale de 1690 à 1779’, Population 39(1): 77-106 
Howlett, John (1792). 'The different quantity and expense of agricultural labour in different years', Annals of Agriculture 18: 76-85

Hufton, Olwen (1974). The Poor of Eighteenth-Century France, Oxford: Clarendon Press

Innes, Joanna (1996). "The "mixed economy of welfare" in early modern England: assessments of the options from Hale to Malthus (c. 1683-1803)', in Martin Daunton (ed.) Charity, Self-Interest and Welfare, London: Routledge, pp. 139-80

Innes, Joanna (1999). 'The state and the poor: eighteenth-century England in European perspective', in John Brewer and Eckhart Hellemuth (eds) Rethinking Leviathan: The Eighteenth Century in Britain and Germany, Oxford: Oxford University Press, pp. 225-80

Jones, Colin (1982). Charity and Bienfaisance in the Treatment of the Poor in the Montpellier Region, 1740-1815, Cambridge: Cambridge University Press

Jordan, W. K. (1959). Philanthropy in England, 1480-1660, London: Allen and Unwin

Jutte, Robert (1994). Poverty and Deviance in Early Modern Europe, Cambridge: Cambridge University Press

King, Steve (1997). 'Poor relief and English economic development re-appraised', Economic History Review 50(2): 360-68

King, Steve (2000). Poverty and Welfare in England, 1700-1850: A Regional Perspective, Manchester: Manchester University Press

Landers, John (1993). Death and the Metropolis: Studies in the Demographic History of London, 1670-1830, Cambridge: Cambridge University Press

Laslett, Peter (1988). 'Family, kinship and collectivity as systems of support in pre-industrial Europe: a consideration of the "nuclear hardship" hypotheses', Continuity and Change 3(2): 153-75

Lesthaeghe, Ron (1980). 'On the social control of human reproduction', Population and Development Review 6(4): 527-48

Levene, Alysa (2003). 'The origins of the children of the London Foundling Hospital 1741-60: a reconsideration', Continuity and Change 18(2): 201-35

McIntosh, Marjorie (1988). 'Local responses to the poor in Medieval and Tudor England', Continuity and Change 3: 209-45

Newbery, David (1989). 'Agricultural institutions for insurance and stabilization', in Pranab Bardhan (ed.), The Economic Theory of Agrarian Institutions, Oxford: Clarendon Press, pp. 267-96

North, Douglas (1981). Structure and Change in Economic History, New York: Norton

Olson, Mancur (1965). The Logic of Collective Action: Public Goods and the Theory of Groups, Cambridge, MA: Harvard University Press

Page, Frances (1930). 'The customary Poor-Law of three Cambridgeshire manors', Cambridge Historical Journal 3(2): 125-33

Platteau, Jean-Phillipe (1991). 'Traditional systems of social security and hunger insurance: past achievements and modern challenges', in Ehtisham Ahmad, Jean Drèze, John Hills and Amartya Sen (eds) Social Security in Developing Countries, Oxford: Clarendon Press, pp. 139-140

Rostow, W.W. (1960). The Stages of Economic Growth: A Non-Communist Manifesto, Cambridge: Cambridge University Press

Rushton, Neil (2001). 'Monastic charitable provision in Tudor England: quantifying and qualifying poor relief in the early sixteenth century', Continuity and Change 16(1): 9-44

Schwartz, Robert (1988). Policing the Poor in Eighteenth-Century France, Chapel Hill: University of North Carolina Press

Slack, Paul (1980). 'Books of orders: the making of English social policy, 1577-1631', Transactions of the Royal Historical Society, 5th ser., 30: 1-22

Slack, Paul (1988). Poverty and Policy in Tudor and Stuart England, London: Longman 
Slack, Paul (1990). The English Poor Law, 1531-1782, Cambridge: Cambridge University Press

Slack, Paul (1992). 'Dearth and social policy in early modern England', Social History of Medicine 5(1): 1-17

Slack, Paul (1998). From Reformation to Improvement: Public Welfare in Early Modern England, Oxford: Clarendon Press

Smith, Richard (1984). 'The structured dependency of the elderly as a recent development: some sceptical thoughts', Ageing and Society 4(4): 409-28

Smith, Richard (1991). 'The manorial court and the elderly tenant in late medieval England', in Margaret Pelling and Richard Smith (eds) Life, Death and the Elderly, London: Routledge, pp. 39-61

Smith, Richard (1996). 'Charity, self-interest and welfare reflections from demographic and family history', in Martin Daunton (ed) Charity, Self-Interest and Welfare in the English Past, London: UCL Press, pp. 23-49

Smith, Richard (1998). 'Ageing and well-being in early modern England: pension trends and gender preferences under the English Old Poor Law, c.1650-1800', in Paul Johnson and Pat Thane (eds) Old Age from Antiquity to Post-Modernity, London: Routledge, pp. 64-93

Snell, Keith (2006). 'Settlement, parochial belonging and entitlement', in Keith Snell (ed.), Parish and Belonging: Community, Identity and Welfare in England and Wales, 1700-1950, Cambridge: Cambridge: University Press, pp. 81-161

Sokoll, Thomas (ed.) (2001). Essex Pauper Letters 1731-1837, Records of Social and Economic History New Series 30, London: British Academy

Solar, Peter (1995). 'Poor relief and English economic development before the industrial revolution', Economic History Review 48(1): 1-22

Solar, Peter (1997). 'Poor relief and English economic development: A renewed plea for comparative history', Economic History Review 50(2): 369-74

Taylor, James (1989). Poverty, Migration and Settlement in the Industrial Revolution: Sojourners' Narratives, Palo Alto, CA: Society for the Promotion of Science and Scholarship

Taylor, James (1991). 'A different kind of Speenhamland: non-resident relief in the industrial revolution', Journal of British Studies 30(2): 183-208

Walter, John and Keith Wrightson (1976). 'Dearth and the social order in early modern England', Past and Present 71(1): 22-44

Walzer, Michael (1983). Spheres of Justice: A Defence of Pluralism and Equality, Oxford: Blackwell

Warde, Paul (2007). 'The origins and development of institutional welfare support in early modern Württtemberg c.1500-1700', Continuity and Change 22(3): 1-29

Wilson, Chris (1986). 'The proximate determinants of marital fertility in England 1600-1799', in Lloyd Bonfield, Richard Smith and Keith Wrightson (eds) The World We Have Gained: Histories of Population and Social Structure, Oxford: Blackwell, pp. 203-30

Wilson, Adrian (1989). 'Illegitimacy and its implications in mid-eighteenth century London: the evidence of the Foundling Hospital', Continuity and Change 4(1): 103-64

Woolf, Stuart (1986). The Poor in Western Europe in the Eighteenth and Nineteenth Centuries, London: Methuen

Wrightson, Keith (1996). 'The politics of the parish in early modern England', in Paul Griffiths, Adam Fox, and Steve Hindle (eds) The Experience of Authority in Early Modern England, London: Macmillan, pp. 10-46

Wrigley, E.A. (1987). People, Cities and Wealth, Oxford: Blackwell

Wrigley, E.A. (1999). 'Corn and crisis: Malthus and the high price of provisions', Population and Development Review 25(1): 121-8

Wrigley, E.A. (2006). 'The transition to an advanced organic economy: half a millennium of English agriculture', Economic History Review 59(3): 436-86 
Wrigley, E.A., Ros Davies, Jim Oeppen and Richard Schofield (1997). English Population History from Family Reconstitution 1580-1837, Cambridge: Cambridge University Press

Wrigley, E.A. and Richard Schofield (1981). The Population History of England: A Reconstruction, London: Edward Arnold

\section{Notes}

1 Some critics, for example, are unwilling to view the Old Poor Law as possessed of systemic qualities because of what is thought to be far too great a variation in the levels of relief from parish to parish and from region to region. Steve King (2000, 1997) has argued that that the numbers of persons in receipt of relief in the late eighteenth century - and what he terms the generosity of support offered to them were much reduced in the north and west of England compared with the south and east (but see Solar 1997). Steve Hindle (2004: 283) has wondered, however, whether this argument about regional differences is 'significantly overdrawn (not to say exaggerated)' and prefers to see it, based on his work in the seventeenth- and early eighteenth-century welfare provisioning and rate-raising to support it, as reflecting 'mosaics of local variation rather than a major regional schism'.

2 See Wrightson (1996), and many other essays in Griffiths et al. (1996).

3 Of course, it did lead to litigation between conflicting parishes regarding their obligations to provide relief to individuals. Also, as the Poor Law was English it did not extend to Scotland and Ireland; paupers from these areas could be removed from the country since they had no legal settlement if recently arrived and if they had not acquired it through the various routes outlined previously (Feldman 2003). This was especially difficult for temporary harvest workers for instance and became a major issue under the New Poor Law in the nineteenth century, especially in the industrial north and around and after the Irish Famine.

4 For an especially balanced, insightful but generally positive assessment of the efficacy of the Settlement Laws under the Old Poor Law, see Snell (2006).

5 It is a moot question how far what emerged in the seventeenth century constituted a manageable and effective trade-off between incentive and co-variance problems in the delivery of welfare. These are issues that are sometimes not fully confronted by students of sixteenth- and seventeenth-century poor relief, but must loom large in any serious attempt to review the equity issues at the core of an emerging parochially focused form of welfare provisioning from the late fourteenth century onwards. While the risk pool in the thirteenth and early fourteenth centuries may have been broader and very loosely structured, by dint of its greater diversity in the matter of forms of charitable provision, it is not at all clear that it was more inclusive in its capacity to deliver assistance to those in need and particularly in its ability to deal with severe dislocation associated with harvest failure. In a thought-provoking essay in which he pursues the fundamental question posed in the title, 'Did the peasants really starve in medieval England?' Chris Dyer (1998) is inclined to say that for the most part after 1375 the answer must be a very definite no. This may well prove to be a more meaningful chronological break-point and one from which an increasingly parochially circumscribed system of revenue-raising and revenue redistribution brings significant equity advances over large tracts of southern Britain.

6 For example, Schwartz (1988) and Adams (1990).

7 A good overview is to be found in Woolf (1986).

8 For an exemplary study of a predominantly rural setting that demonstrates very clearly the central features of rural government and social policy in the late eighteenth and early nineteenth centuries see Eastwood (1994). 
9 This discussion of the evidence collected by the Committee of Mendicity is based on Hufton (1974: chapter 5).

10 Neil Rushton's reworkings of the evidence created by the Valor Ecclesiasticus of 1535 shows that religious houses, broadly defined, may have been expending up to $£ 13,000$ on charitable activities. In so far as the wealthiest and most significant contributors to this sum were operating in the larger urban provincial setting the loss of this source of charitable assistance removed a substantial element in welfare resources from urban populations. It should not be forgotten that the bulk of this income had been received from what might be regarded as an urban levy on the countryside in the form of rents and payments in kind for rural manors or farms (see Rushton 2001).

11 It might be wise not to overplay the speed with which these practices became so extensive over rural settings. Paul Slack was inclined when writing in the 1980s on this subject to suggest that as late as 1660 only a third of English parishes were raising rates (see Slack 1988: 179), although by 1700 a large majority were doing so. Steve Hindle (2004: chapter 4) argues that Slack's diagnosis may have been too pessimistic regarding the speed with which rural overseers in association with JPs were able to establish a nationwide system of rate-based revenue raising.

12 These observations are based on the findings from work in progress on the spatial patterning of relief expenditure revealed in the Board of Trade enquiry of 1696 and parliamentary enquiries of $1748-50,1776,1783-85$ and 1802-03.

13 For a useful analysis of letters written by and settlement examinations of Londonbased persons seeking relief from rural and non-metropolitan parishes, see Taylor (1989). Arguments are taken further in Taylor (1991).

14 But see Hadwin (1978).

15 See also Innes (1996).

16 We may stress this contrast, cognisant of Adrian Wilson's attempt to estimate illegitimacy ratios in mid-eighteenth century London through concentration upon the foundlings taken into the newly established London Foundling Hospital during the period of the so-called General Reception between 1756 and 1760 (Wilson 1989). Wilson estimated that the majority of those received were illegitimate and that they constituted a ratio of 10-12 percent of London births (50 percent by women who had come to the capital specifically to give birth). Alysa Levene (2003) has very recently shown that Wilson's work has produced a significant overestimation of metropolitan illegitimacy and suggests that illegitimate foundlings may have accounted for 50 rather than 80-90 percent of the London Foundling Hospital intake, as argued by Wilson. Her findings suggest a significant downgrading of the incidence of metropolitan illegitimacy. Even if we were to allow Wilson's initial estimate to stand, the drawing power of that massive metropolitan centre with 10-12 percent of the nation's population seems muted compared with proportionally far larger flows of mothers and offspring to the much smaller French urban centres. If, as Wilson suggests, a true ratio of illegitimacy in London in the mid-eighteenth century was closer to 5 percent, compared with 3-4 percent in the provinces, it could still be argued that London was not an environment that specifically encouraged illegitimacy or the immigration of unmarried mothers to it. The proportion of London's unmarried female population at risk to give birth to bastards was much higher than in the provinces, so an illegitimacy ratio in excess of those in the countryside by a margin of a couple of percent most likely implies an illegitimacy rate (per 1000 unmarried females) that was actually lower than in rural areas, as in fact applies when we have access to the first returns from the Registrar General in the nineteenth century. 
17 Rates of mortality among foundlings could range from 700-900 per 1000; see Jones (1982: 45-94) and Bardet (1983: 337).

18 As is well known, the study of infant mortality in seventeenth- and eighteenthcentury France is not straightforward because of the difficulties associated with the under-registration of infant and child deaths. French historical demographers have developed methods to correct these shortcomings which now offer us reasonably robust data sets that may be regarded with considerable confidence. The most comprehensive sample is that reported by Jacques Houdaille who notes an overall improvement in infant mortality rates from 1690 to 1780 , but notwithstanding the decline, the rates revealed make for fairly depressing reading when set alongside the equivalent English evidence (see Houdaille 1984). Even in the French region with the lowest infant mortality, the south-west, where breastfeeding is thought to have been almost ubiquitous, infant mortality rates in the 1690 s were close to 200 per 1000 . Rates of 275 to 350 per 1000 are encountered in eastern and north-eastern France where breastfeeding was less common or of a shorter duration. In fact, Houdaille's national estimates range from 350 per 1000 in 1690-1719 to 320 in 1720-49 and fall to 263 in the period 1750-79. Parish family reconstitutions prepared by the Cambridge Group for the History of Population and Social Structure from a reasonably large sample of English registers suggest that infant mortality rates in the 1690 s and early 1700 s may have reached c. 195 per 1000 , but thereafter fell so that in the period 1720-49 rates were approximately 180 per 1000 and by the third quarter of the century had fallen to 150 when those in France were still in excess of 260 per 1000 (see Wrigley et al. 1997: 214-48).

19 It is worth noting that historians, when confronted with differences of the order of magnitude displayed by these data sets, have reacted in various ways. French historical demographers have tended to doubt the accuracy of English registers and regard the low rates as an 'under-registration' effect; others resort to arguments that seek an explanation squarely within the differences in basic productivity of the French and English agrarian systems. Of course, such an explanation is deserving of serious consideration and the evidence relating to substantial superiority of English over French levels of agricultural productivity is indeed compelling. Nonetheless, it is not at all clear that nutritional factors should be regarded as decisive in determining these differences. It is doubtful whether patterns of breast-feeding in the first six months of life varied as much as they did after the first six months of life, but nonetheless we find contrasts between France and England that stand out in the early as well as the latter parts of the first year and the subsequent years 1-4 and 5-9, pointing, it would seem, to the importance of factors to do with the quality of the domestic environment and other features and procedures connected with child care and household income (compare infant and child mortality rates reported in Houdaille (1984) with those reported in Wrigley et al. (1997: 214-48).

20 For the seventeenth and early eighteenth centuries the French mortality series are plagued by the under-recording of infant and young child deaths so the comparison between France and England has to be based on deaths relating to the population above age five.

21 This is a subject evidently needing further comparative assessment involving work on English and French urban centres of the seventeenth and eighteenth centuries. It would be valuable to know whether the 'urban effect' during periods of high food prices was more marked in France than in England, therefore reflecting the greater spatial unevenness of welfare provision, social and political intervention in 
the latter than the former society. It would also be interesting to know whether the mortality enhancements were as socially undifferentiated in one urban system as in the other.

22 The technical basis of this claim is to be found in Wrigley and Schofield (1981: 236-40). 